\title{
Growth rate of a terra firme rain forest in brazilian amazonia over an eight-year period in response to logging ${ }^{1}$.
}

\author{
João Olegário Pereira de CARVALHO², José Natalino Macedo SILVA², José do Carmo Alves LOPES 3
}

\begin{abstract}
This paper deals with growth rates of trees $\geqslant 5 \mathrm{~cm}$ dbh over an eight-year period from 257 species at the Tapajós National Forest. The discussion is centred on the behaviour of the forest after logging. Permanent sample plots were established in 1981 and measured at the first time. The area was logged in 1982. Measurements after logging occurred in 1983, 1987 and 1989. Considering all species together, diameter increment was similar for both intensities of logging until five years after logging. Light-demanding species showed significantly higher growth rates than shade-tolerant species in the logged forest, with greater increment in the heavier treatment intensity. Commercial species also had higher growth rates in the heavier logged area, although those were significantly different only in the period from one to five years after logging. In the undisturbed forest, growth rates increased with increasing $\mathrm{dbh}$ size. At species level, growth rate varied between and within treatments, as well as between trees within species, depending mainly on degree of canopy opening. The logging favoured the growth of commercial species, chiefly the light-demanders. Therefore, if the same growth conditions continue being given, for example by silvicultural treatments, to those species of commercial interest, the forest would reach a stock available for harvesting around year 30 after logging. However, the high variation in increment rates indicates that an eight-year period is not sufficient to allow predictions on cutting cycles or polycyclic management systems for the study forest.
\end{abstract}

\section{KEY WORDS}

Amazonian forest, tree growth rate, diameter increment, forest dynamics, logging.

\section{Crescimento de uma floresta de terra firme na Amazônia brasileira em um período de oito anos após a exploração florestal.}

\begin{abstract}
RESUMO
É analisado o crescimento de 257 espécies arbóreas, considerando indivíduos com DAP $\geqslant 5 \mathrm{~cm}$, na Floresta Nacional do Tapajós, em um período de oito anos. Em 1981 foram estabelecidas parcelas permanentes, e medidas pela primeira vez. Em 1982 a área foi explorada. Medições após a exploração foram realizadas em 1983, 1987 e 1989. Considerando todas as espécies juntas, o incremento em diâmetro foi similar nas duas intensidades de exploração, até o quinto ano após a colheita. As espécies intolerantes à sombra mostraram crescimento significativamente maior do que as espécies tolerantes à sombra na floresta explorada, com maior incremento na área de exploração mais pesada. Espécies comerciais também tiveram crescimento maior nessa mesma intensidade de exploração, embora tenham sido significantemente diferentes apenas entre o primeiro e o quinto ano após a exploração. Na floresta não-explorada, as árvores com diâmetros maiores apresentaram maior crescimento. Em nível de espécies, o crescimento variou entre e dentro das diferentes intensidade de exploração, assim como entre as árvores dento de uma mesma espécie, dependendo principalmente do grau de abertura do dossel. A exploração favoreceu o crescimento de espécies comerciais, principalmente intolerantes à sombra. Se as mesmas condições de crescimento continuarem sendo proporcionadas, por exemplo através de tratos silviculturais, para essas espécies de interesse, a floresta atingirá um estoque disponivel para nova colbeita cerca de 30 anos após a exploração. Entretanto, a alta variação na taxa de incremento indica que o período de oito anos não é suficiente para permitir predições seguras quanto a ciclos de corte ou sistemas de manejo policíclico para a floresta estudada.
\end{abstract}

PALAVRAS-CHAVE

Floresta amazônica, crescimento de árvores, incremento diamétrico, dinâmica de florestas, exploração florestal.

\footnotetext{
${ }^{1}$ This paper is part of the results of the "Forest Structure Project" (08.2000.024), Embrapa Amazônia Oriental.

${ }^{2}$ Forest Researcher, Ph.D., Embrapa Amazônia Oriental, Caixa Postal 48, CEP66017-970, Belém, PA. E-mail: olegario@cpatu.embrapa.br, natalino@cpatu.embrapa.br

${ }^{3}$ Forest Researcher, M.Sc., Embrapa Amazônia Oriental, Caixa Postal 48, CEP 66017-970, Belém, PA. E-mail: carmo@cpatu.embrapa.br
} 


\section{ACTA \\ AMAZONICA}

GROWTH RATE OF A TERRA FIRME RAIN FOREST IN BRAZILIAN

AMAZONIA OVER AN EIGHT-YEAR PERIOD IN RESPONSE TO LOGGING

\section{INTRODUCTION}

Data on ingrowth, mortality and diameter increment are needed for predicting future stand tables in tropical rain forest. Growth rate is one of the paramount factors to be taken in account in forest management planning. There are many different opinions about correlation between growth rate and mortality. Mervart (1972), Nicholson (1979) and Swaine (1990) reported that slower growing trees show a higher mortality with time. Rai (1981) studied two tree species in the wet evergreen forests of the Western Ghats, India, and found that the faster growing species had an annual mortality of $1.62 \%$ and the lower had $1.96 \%$. On the other hand in mixed indigenous forests in Peninsular Malaysia, Tang \& Wan-Razali (1981) noted that slower growing species had intermediate mortality rates, and both the highest and the lowest rates were observed on the two fastest growing species. Singh (1981), in wet evergreen tropical forests in India, found an unweighed mean mortality of $1.11 \%$ for 30 species. He analyzed data over a 15 -year period and observed no correlation between growth rate and mortality. Also Silva (1989) reported practically no relationship between these variables in a logged area in Brazilian Amazonia over a six-year period.

The aim of this paper is to analyze the growth rates of trees $\geqslant 5 \mathrm{~cm}$ dbh from 257 species at the Tapajós National Forest over an eight-year period. The discussion will be centred on the behaviour of the forest after logging, compared to the undisturbed area, in order to answer some questions which will give valuable information in making decisions about the silvicultural system to be adopted in the Brazilian Amazonia. The following main questions should be answered: Is the logging favourable to grow species of any ecological group? What is the effect of logging on the growth and dynamics of species of economic interest?

\section{MATERIAL AND METHODS}

\section{The study area}

The study area is in Tapajós National Forest $\left(2^{\circ} 40^{\prime}-4^{\circ}\right.$ $\left.10^{\prime} \mathrm{S}, 54^{\circ} 45^{\prime}-55^{\circ} 30^{\prime} \mathrm{W}\right)$ near kilometer 114 of the SantarémCuibá Road (BR 163) in the municipality of Belterra, State of Pará, Brazil. Tapajós National Forest area is about 600,000 ha at an altitude of $c .175 \mathrm{~m}$ above the sea level. The climate is classified by Köppen as Ami, mean annual air temperature is $c .25^{\circ} \mathrm{C}$, mean relative humidity is $86 \%$ (76-93\%), mean annual rainfall is $2110 \mathrm{~mm}$ with high rainfall from March to May, and low rainfall from August to November (Carvalho, 1982). The topography is mostly level or slightly rolling. Soil is alic to moderate yellow latosol with heavy clay texture (60-94\% clay), with inclusions of concretionary yellow latosol, derived from clay stone (Fundação de Pesquisas Florestais do Paraná, 1986). Following the general pattern for the soils of terra firme Amazonian forests, it is low in nutrients. Dubois (1976) classified the forest type as zonal primary high terra firme forest without babaçu palm (Orbygnia barbosiana Burret).

\section{METHODS}

The research was set up in 1981 by carrying out $100 \%$ pre-logging forest inventory of trees $\geqslant 45 \mathrm{~cm} \mathrm{dbh}$ in $144 \mathrm{ha}$. At the time of the initial inventory, all lianas were cut and 48 permanent sample plots were established and measured for the first time within the 144 ha. In 1982 the area was logged. The subsequent measurements took place in 1983 - one year after logging, 1987 - five years after logging and in 1989 - seven years after logging. A 36 ha unlogged control area with 12 permanent plots was established in 1983. It was first measured then and later in 1987 and 1989.

The forest structure was similar in both the T1 and T2 areas before logging and in the control block (Carvalho, 1992). The experienced Embrapa research team carried out logging. Chainsaws were used for cutting. An attempt was made at directional felling and a wheeled skidder was used, operating in trails planned and previously opened by a bulldozer. Particulars of each treatment are as follows:

T1 - this treatment consisted of cutting trees of 38 species $\geqslant 45 \mathrm{~cm} \mathrm{dbh}$. This $\mathrm{dbh}$ limit was applied because it is the minimum permitted by the Brazilian Forest Law for felling trees in natural forests. The 38 species were selected from a list of commercial species in the regional timber market based on their abundance, basal area, and timber volume recorded in a previous forest inventory carried out in the study area (Silva et al., 1985). In this treatment, 14 trees ha${ }^{1}$ were cut $\left(69 \mathrm{~m}^{3} \mathrm{ha}^{-1}\right)$.

T2 - cutting of trees of the same 38 commercial species as in T1 but $\geqslant 55 \mathrm{~cm} \mathrm{dbh}$. This diameter limit was applied because generally the sawmills in the Tapajós region are set to use logs $\geqslant 45 \mathrm{~cm}$ diameter. The top diameter of a bole might only measure $45 \mathrm{~cm}$ if its $\mathrm{dbh}$ is at least $50 \mathrm{~cm}$, although this varies from one species to another. The decision to take $55 \mathrm{~cm}$ as the cutting limit assumed that all trees felled would have a diameter greater than $45 \mathrm{~cm}$ at any part of their bole. This does not allow for any loss of timber, which occurs, with trees of $45 \mathrm{~cm} \mathrm{dbh}$, which is the traditional cutting limit in Amazonia. In this treatment, 11 trees ha ${ }^{-1}$ were cut $\left(78 \mathrm{~m}^{3} \mathrm{ha}^{-1}\right)$.

T0 - the control area remained in its natural untreated condition.

The statistical design of the treatments constituted four randomized blocks. Each treatment was replicated four times, with one 9 ha treatment plot per block. The control was a separate block also divided into four plots, each of 9 ha. Each plot was sub-divided into nine 1 ha quadrats. Three of which were selected at random. A $50 \mathrm{~m} \times 50 \mathrm{~m}$ permanent sample-plot was set in the center of each. Following the procedure of Silva \& Lopes (1984), each permanent sampleplot was further divided into 25 subsample-plots of $10 \mathrm{~m} \mathrm{x}$ $10 \mathrm{~m}$ and marked with permanent top-red-painted stakes. 


\section{ACTA AMAZONICA}

GROWTH RATE OF A TERRA FIRME RAIN FOREST IN BRAZILIAN AMAZONIA OVER AN EIGHT-YEAR PERIOD IN RESPONSE TO LOGGING
All individuals $\geqslant 5 \mathrm{~cm}$ dbh were number-tagged, identified and measured. In total, each treatment was applied over 36 ha, and included 3 ha of measured sample-plots.

The guidelines proposed by Synnott (1979) and Whitmore (1989b) for the measurement of the permanent sample-plots in tropical rain forests were followed. Further procedures in measurement were based up on Hutchinson (1982) and Silva \& Lopes (1984), described also in Silva (1989). The main guidelines or procedures are: diameter of trees $\geqslant 5 \mathrm{~cm}$ dbh was measured at breast hight $(\mathrm{dbh})$ or above the buttress; the point of measurement was marked at the first assessment with a painted half ring, renewed if necessary at the subsequent measurements. In buttressed trees, the point of measurement was sometimes several meters high, particularly in the case of Couratari oblongifolia, whose buttress easily reaches more than 5 meters in height. Saplings (individuals $2.5-5.0 \mathrm{~cm} \mathrm{dbh}$ ) received consecutive numbers in the field sheets but were not number tagged in the forest. Records were made of the stem quality, vernacular and botanical identification, wood quality group and dbh size. Diameter of seedlings (individuals between $30 \mathrm{~cm}$ height and $2.5 \mathrm{~cm} \mathrm{dbh}$ ) were not recorded. The number of plants per species was counted. Other variables also described in Silva and Lopes (1984), such As crown illumination, crown form, stem lean and stability, injury, decay, woody climbers competition, forest classes and leading desirable, were recorded, but they were not analyzed in the present study.

Individual trees were identified by their vernacular names in the forest. Botanical specimens were collected from less common trees for later identification in the Embrapa Herbarium. Whenever possible, identification was made to the species level (Carvalho, 1992). Species were classified by their wood quality group and ecological class (light-demanding or shade-tolerant species). The wood quality groups were: commercial - species presently sold in the national or international market; potential - species likely to be sold in the near future, mainly on account of their wood properties; noncommercial - species not marketable, or species whose wood is not yet sufficiently known. This classification was based on wood characteristics and timber markets in Brazil and abroad, according to Instituto... (1980, 1981, 1988), SUDAM (1981), Silva (1989) and Teixeira et al. (1988).

The species were further classified as light-demanding or shade-tolerant species, based on the requirement of their seedlings for solar radiation observed casually in the field during the study period (Carvalho, 1992), and according to distinguishing characters (seed size, early or late production of seed, seed dispersion, dormant or orthodox seed, seedling carbon-fixation, growth rate, wood color, wood density, among others) suggested by Swaine \& Whitmore (1988) and Whitmore (1989a, 1990).

Analyses of variance were used to compare the treatments T1 and T2, and logged and unlogged forests. Initially, two-way analyses of variance were performed, as a randomized block design. Since there were no significant differences between the blocks ( $p>0.05)$, one-way analyses of variance were applied in each case.

\section{RESULTS AND DISCUSSION}

\section{Diameter increment}

Mean diameter increment for trees $\geqslant 5 \mathrm{~cm} \mathrm{dbh}$ from 257 species was very similar between the two treatments in the logged forest for the eight-year study period, averaging $0.37 \mathrm{~cm}$ year ${ }^{-1}$ after logging of trees $\geqslant 45 \mathrm{~cm} \mathrm{dbh}$ and $0.36 \mathrm{~cm}$ year ${ }^{-1}$ after logging of trees $\geqslant 55 \mathrm{~cm} \mathrm{dbh}$. No significant differences were found between the two logging intensities during the entire study period; however, some slight differences were observed between the treatments over shorter periods, i.e. from one measurement to the next. Considering only the period from year 5 after logging to the end of the study period, growth rate differed significantly between the two logging intensities (Fig. 1a). Comparing the treatments in the logged forest to the unlogged, the growth rates were significantly different over the study period, with the unlogged forest showing an increment of only $0.20 \mathrm{~cm}_{\text {year }}{ }^{-1}$, as would be expected from the different forest conditions.

Although in fact agreeing with the statement of Silva (1989) that 'it is very difficult, not to say almost impossible, to compare growth rates from different tropical rain forests in the world' due to many factors, quoted by him, affecting plant growth, some studies were chosen to be mentioned in this paper for simple comparisons. Silva (1989) found a mean diameter increment of $0.50 \mathrm{~cm}_{\text {year }}{ }^{-1}$ for trees $\geqslant 5 \mathrm{~cm} \mathrm{dbh}$ during a six-year period (1981-1987) in an over logged area, also at the Tapajós National Forest. This rate was higher than that found in the present study. Alder (1983) also found higher rates for disturbed or secondary humid tropical forests. He compared data from twelve different studies in seven countries, from all of which, he presented a mean diameter increment of $0.52 \mathrm{~cm}$ year ${ }^{-1}$. He also stated that mean rates of diameter increment in the mixed forests of the humid tropics range from 0.1 to $0.8 \mathrm{~cm}$ year ${ }^{-1}$ for groups of species.

In the same plots studied by Silva (1989) but in the period 1992-1997, Costa et al. (2004) found a mean diameter increment of $0.25 \mathrm{~cm}$ year ${ }^{-1}$ and in the period $1981-1987$ they found $0.30 \mathrm{~cm}$ year ${ }^{-1}$ that was equal to that found by Silva et al. (1995) in 1981-1992, also in the same plots. These rates are lower than that found in the present study $\left(0.37 \mathrm{~cm} \mathrm{year}^{-1}\right)$.

In general, light-demanding species showed significantly higher growth rates than shade-tolerant species in both logging intensities; their increment was greater after logging $\geqslant 45 \mathrm{~cm} \mathrm{dbh}$ (Fig. 1c,d). Over the period, only from before logging to one year after logging (1Y) there was no significant difference in increment found between the two ecological groups. There were eight light-demanding among ten species with higher increment over the period in both treatments. It is worth noting that only one species, Parkia 


\section{ACTA AMAZONICA}

GROWTH RATE OF A TERRA FIRME RAIN FOREST IN BRAZILIAN AMAZONIA OVER AN EIGHT-YEAR PERIOD IN RESPONSE TO LOGGING gigantocarpa, was common to the ten with higher increment in both treatments. Most growth studies in tropical forests have demonstrated that light-demanding species were the fastest growing (see Lieberman \& Lieberman, 1987; Manokaran \& Kochummmen, 1987; Silva, 1989; Silva et al., 1996 and Costa et al., 2004, among others).

Commercial species also showed higher growth rate after logging $\geqslant 45 \mathrm{~cm}$ dbh than after logging $\geqslant 55 \mathrm{~cm}$ dbh (Fig. $1 c, d)$, but significantly different only in the period from one to five years after logging. The shade-tolerant Carapa guianensis, Manilkara buberi and Virola melinonii and the light-demanding Hymenaea parviflora, Parkia multijuga and Terminalia amazonica were the commercial species with high increments in both logging intensities.

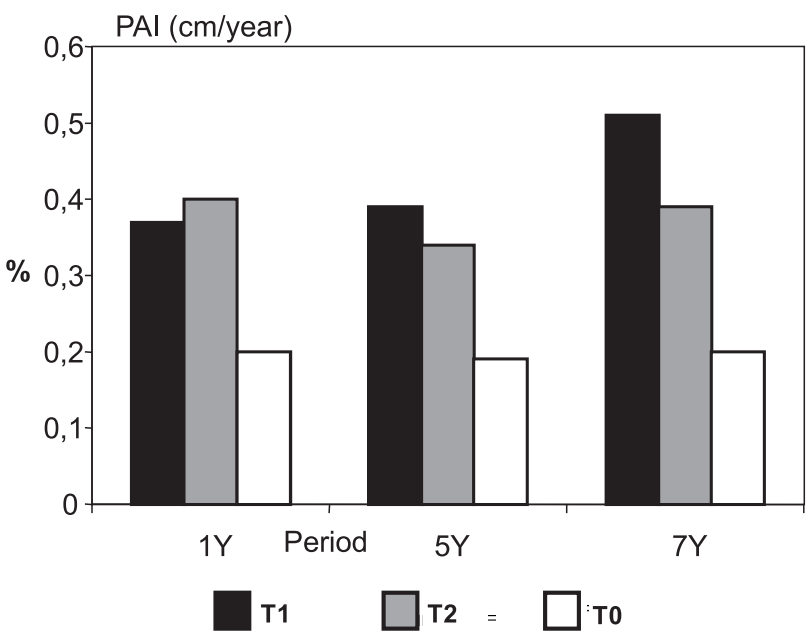

a) Diameter increment over the study period

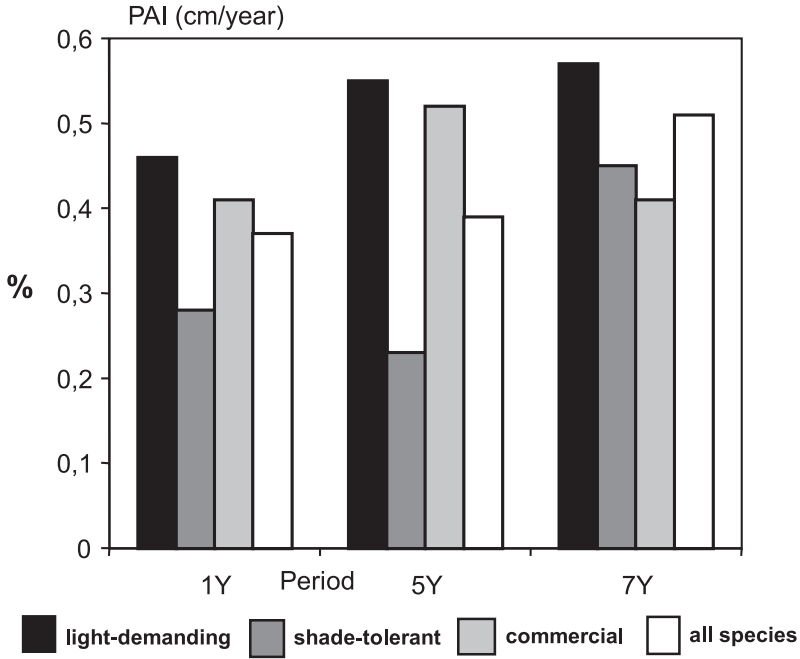

c) Increment after logging $>45 \mathrm{~cm}$ dbh (14 trees/ha)
Trees were divided into three size groups according to dbh. Individuals of $5 \mathrm{~cm} \leqslant \mathrm{dbh} 25 \mathrm{~cm}$ formed the small group, those of $25 \mathrm{~cm} \leqslant \mathrm{dbh}<45 \mathrm{~cm}$ were placed in the medium group, and all those of $\mathrm{dbh} \geqslant 45 \mathrm{~cm}$ were considered in the big size group. No significant differences were found between the size classes in the logged area, except for small trees in the first year after logging $\geqslant 55 \mathrm{~cm}$ $\mathrm{dbh}$, and for medium trees in the fifth year after logging $\geqslant$ $55 \mathrm{~cm} \mathrm{dbh}$. Small size trees, which in general belong to the understorey, grew slowly over the period with a peak, in the logged area, from year 1 to year 5 after logging. Medium sized individuals had a medium increment with a decline in the period between year 1 and year 5 after logging. On the other hand, significant differences were found in the

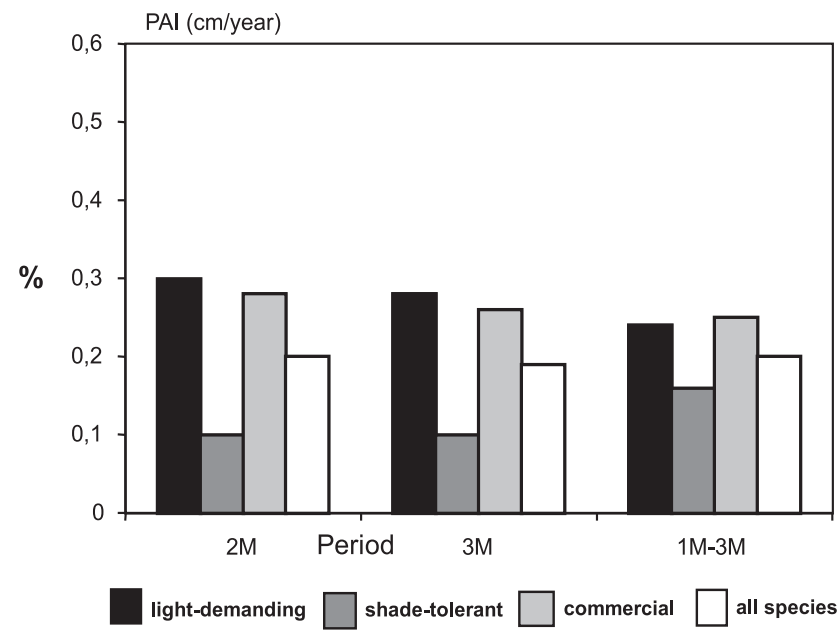

b) Diameter increment in the unlogged area

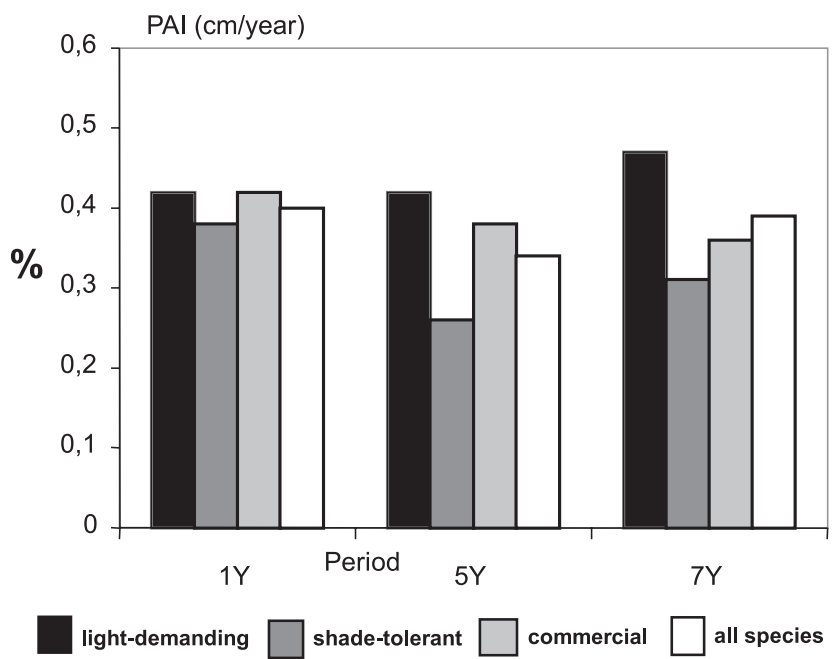

d) Increment after logging $>55 \mathrm{~cm}$ dbh (11 trees/ha)

Figure 1 - Diameter increment for species groups of trees $\geqslant 5 \mathrm{~cm}$ dbh over an 8-year period in Brazilian Amazonia. T1 $=$ logging $\geqslant 45$ $\mathrm{cm} \mathrm{dbh}, \mathrm{T} 2=$ logging $\geqslant 55 \mathrm{~cm}$ dbh, T0 $=$ unlogged forest, $1 \mathrm{y}=1$ year after logging $\ldots, 2 \mathrm{M}=2^{\text {nd }}$ measurement $\ldots$ 


\section{ACTA AMAZONICA}

unlogged area, where small size trees showed lower growth rates, while medium trees had medium increment and large individuals higher increment (Fig. 2). The highest increments occurred in the largest trees, as has been reported in many other growth studies elsewhere (see Miller, 1981; Connell et al., 1984; Weaver, 1986; Lieberman et al., 1985; Lieberman \& Lieberman, 1987; Silva, 1989, among others). According to Swaine et al. (1987) 'this results from four confounded sources: (1) larger trees are more likely to have their crowns in full sunlight, (2) larger trees have greater net production (bigger crowns), (3) slow-growing individuals are more likely to have been eliminated when small and (4) larger tree size classes exclude understorey species which typically have lower growth rates'. This statement may not be valid for recently logged forests, as seen in the present study, where all tree size classes have similar light conditions.

Diameter increment by dbh classes displayed very similar curves between the treatments in the logged forest and also between these and the unlogged area, up to class $7(65 \mathrm{~cm} \leqslant \mathrm{dbh}<75 \mathrm{~cm})$. The larger classes showed higher growth rates, but there were different trends, although these were not significant. This was due to the logging, which left only a few trees in those high dbh classes, and also changed the conditions of the forest. The unlogged forest showed similar increment for each period studied separately and for the entire period. Significant differences in diameter increment by dbh class were found only in the two smaller classes $(5 \mathrm{~cm}-25 \mathrm{~cm} \mathrm{dbh})$ between logged and unlogged forest. In the present study, taking into account the mean annual diameter increment in each treatment, trees from dbh class $3(25 \mathrm{~cm} \leqslant \mathrm{dbh}<35 \mathrm{~cm})$ will reach the cutting limit $(\mathrm{dbh} \geqslant 45 \mathrm{~cm})$ at year 27 after logging at the heavier intensity, while trees from dbh class $4(35 \mathrm{~cm} \leqslant \mathrm{dbh}<45 \mathrm{~cm})$ will attain the limit $(\mathrm{dbh} \geqslant 55 \mathrm{~cm})$ at year 28 after logging in the lighter logged area.

Differences in increment between the two logging intensities in the first period, one year before logging (BL) and year 1 after logging (1Y), resulted mainly from growth of Parkia gigantocarpa, Tachigalia myrmecopbylla and Sloanea spp. in dbh class $8(75 \mathrm{~cm} \leqslant \mathrm{dbh}<85 \mathrm{~cm})$ after logging $\geqslant 45 \mathrm{~cm} \mathrm{dbh}$, and also Swartzia acuminata in classes $10(95 \mathrm{~cm} \leqslant \mathrm{dbh}<105 \mathrm{~cm})$ and $11(\mathrm{dbh} \geqslant 105 \mathrm{~cm})$. In the second period, from year 1 to year 5 after logging $(1 \mathrm{Y}-5 \mathrm{Y})$, the differences again were due to those species in the more intensive logging and also because of a tree of Swartzia acuminata that moved from class 10 to 11 in the less intensive logging. In the last two years of the study period, from year 5 to year 7 after logging (5Y-7Y), the species mostly responsible for these slight changes were Enterolobium schomburgkii, Parkia gigantocarpa, Sloanea spp., Swartzia acuminata and Chimarris turbinata, which showed higher increment after logging $\geqslant 45 \mathrm{~cm} \mathrm{dbh}$ from $\mathrm{dbh}$ class 8 to 11 . Also after logging $\geqslant 55 \mathrm{~cm} \mathrm{dbh}$, the increment curve showed a peak in dbh class 10 due to the change of a Brosimum obovata tree from dbh class 9 .

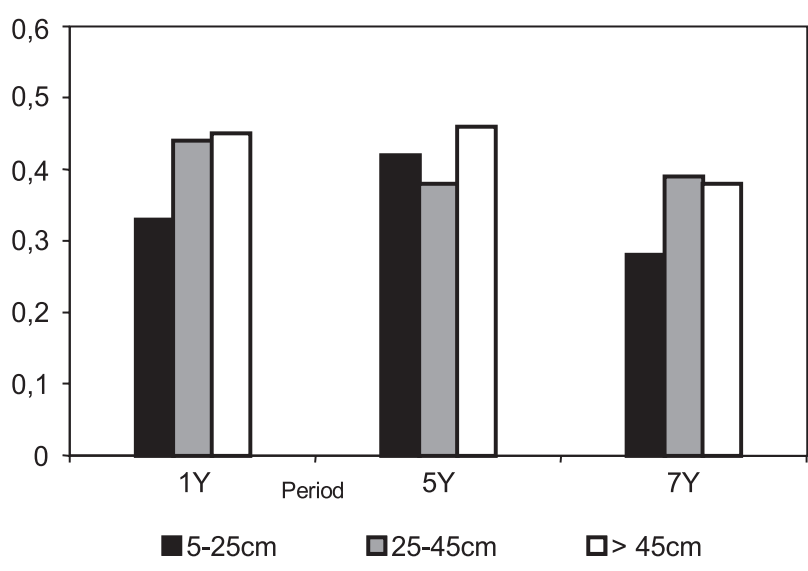

a) Diameter increment after logging $>45 \mathrm{~cm}$ dbh (14 trees/ha)

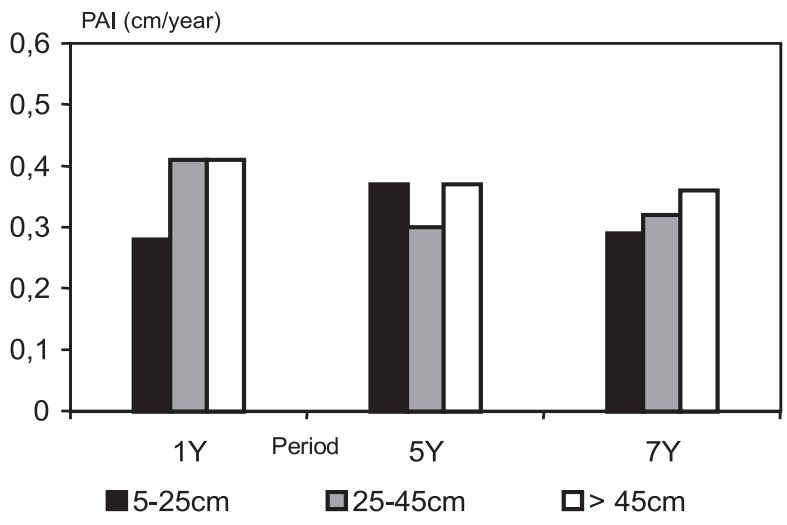

b) Diameter increment after logging $>55 \mathrm{~cm} \mathrm{dbh}(11$ trees $/ \mathrm{ha})$

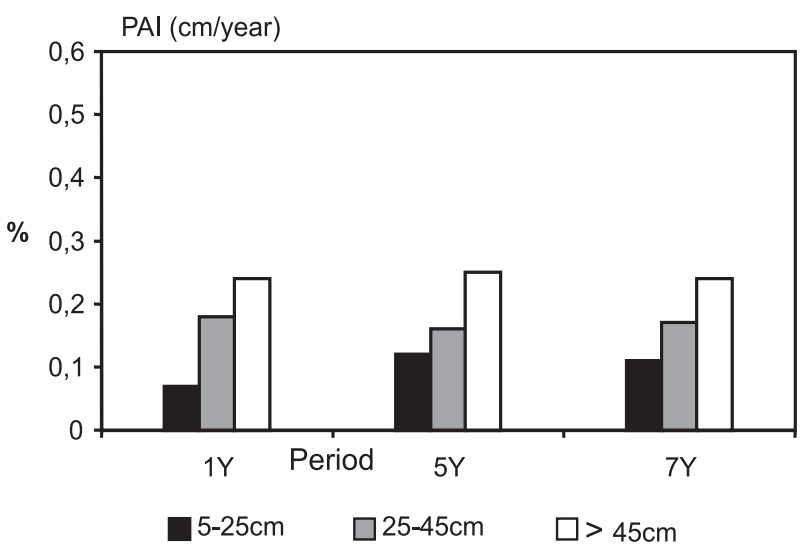

c) Diameter increment in the unlogged forest

Figure 2 - Diameter increment of trees $\geqslant 5 \mathrm{~cm}$ dbh for three dbh size classes $(5-25 \mathrm{~cm} d b h ; 25-45 \mathrm{~cm} d b h ; \mathrm{dbh}>45 \mathrm{~cm})$ over an 8year period in Brazilian Amazonia. T1 $=$ logging $\geqslant 45 \mathrm{~cm} \mathrm{dbh}$, T2 $=$ logging $\geqslant 55 \mathrm{~cm} \mathrm{dbh}, \mathrm{T} 0=$ unlogged forest, $1 \mathrm{y}=1$ year after $\operatorname{logging} \ldots, 2 \mathrm{M}=2^{\text {nd }}$ measurement $\ldots$ 


\section{ACTA AMAZONICA}

GROWTH RATE OF A TERRA FIRME RAIN FOREST IN BRAZILIAN

AMAZONIA OVER AN EIGHT-YEAR PERIOD IN RESPONSE TO LOGGING
The growth rate in the unlogged forest showed some changes in the higher dbh classes in the first period. But the increment curve was very similar between the second period (2M-3M) and the entire study period (1M-3M). However, the unlogged forest was also dynamic. The mean growth rate of $0.20 \mathrm{~cm}$ year ${ }^{-1}$ was higher than $0.14 \mathrm{~cm}$ year ${ }^{-1}$ found by Gomide (1999) in a primary rain forest in Amapá State, Brazilian Amazonia, but lower than the mean $0.26 \mathrm{~cm}$ year ${ }^{-1}$ found by Lieberman et al. (1985) in a primary wet forest in La Selva, Costa Rica, though the fast-growing trees in the present study showed increments in the range of $0.50-2.00 \mathrm{~cm}$ year ${ }^{-1}$ that they stated for 'relatively fastgrowing trees in wet tropical forests'.

Considering the eight-year study period, the periodic increment curves show that lower growth rates were found for trees in lower dbh classes (trees $<25 \mathrm{~cm} \mathrm{dbh}$ ), in both logged and unlogged forests. Their increment curves were similar, except for two peaks after logging $\geqslant 45 \mathrm{~cm} \mathrm{dbh}$. The first happened in class 8 (trees $75-84.9 \mathrm{~cm} \mathrm{dbh}$ ), owing to high increment of Parkia gigantocarpa and Sloanea spp., and the second in class 10 (trees $95-104.9 \mathrm{~cm} \mathrm{dbh}$ ) due to Swartzia barchirrachis and Chimarris turbinata. Those species in class 8 are light-demanding, while those in class 10 are shade-tolerant.

Variations in diameter increment between species within treatments were wide $(\mathrm{CV}=88 \%$ in the more intensive logging, $67 \%$ in the less intensive logging, $98 \%$ in the unlogged area. Diameter increment likewise varied between trees within species reflecting 'the great difference in the extent of crown illumination and other growth conditions of individual trees, which may be affected by genetic differences as well', as suggested by Swaine et al. (1987) and by Begon (1984), who said that individuals even within a population differ from one another in their genotypes, and in the phenotypic manifestations of these genotypes'. For that reason, Mervart $(1972,1974)$ was concerned about the use of increment and mortality for predicting stand tables. Kio (1978) recommended that proper management and silvicultural techniques should create conditions under which some individual trees would attain growth rates approaching the maximum recorded for the species.

In both logged and undisturbed forest, more than 60 species showed growth rates above the general mean. The five species with the highest increment after logging $\geqslant 45 \mathrm{~cm}$ dbh were Alexa grandiflora, Miconia spp., Goupia glabra, Stryphnodendron pulcherrimum, and Swartzia acuminata. In the less intensive logging (trees $\geqslant 55 \mathrm{~cm} \mathrm{dbh}$ ) they were Bixa arborea, Cecropia obtusa, Dipteryx odorata, Sclerolobium chrysophyllum and Sclerolobium guianensis, and in the unlogged area they were Caryocar glabrum, Enterolobium schomburgkii, Goupia glabra, Jacaranda copaia and Qualea paraensis. Nearly 50 species showed dbh increment lower than $0.20 \mathrm{~cm}^{-1} \mathrm{ear}^{-1}$ in the logged area, mainly those understorey species such as Ambelania grandiflora, Anona montana, Clavija lancifolia, Diospyros tetandra, Eugenia sp., Randia armata and Talisia spp., among others.
Each species has a particular development in diameter growth. There are various different groups of increment curve patterns for species in the undisturbed forest. But after logging, many species, mainly light-demanding, changed their curve pattern strongly. Examples of those changes were the species Piptadenia suaveolens and Apeiba burchellii. The first had a very small increment in the lower diameter class $(5 \mathrm{~cm} \leqslant \mathrm{dbh}<15 \mathrm{~cm})$ in the unlogged forest, with a peak in class $3(25 \mathrm{~cm} \leqslant \mathrm{dbh}<35 \mathrm{~cm})$, declining slightly in the higher classes, but in the logged area increment was higher for trees $<25 \mathrm{~cm}$ dbh, then very little for trees $25-65 \mathrm{~cm}$ dbh and very high for large trees. Aniba burchellii showed similar increment for trees $<25 \mathrm{~cm}$ dbh in both logged and unlogged areas, while trees $>25 \mathrm{~cm}$ dbh had a very small increment in the unlogged area, but very high in the logged forest. On the other hand, light-demanding species such as Bixa arborea and Neea floribunda showed a similar trend in both logged and unlogged forests.
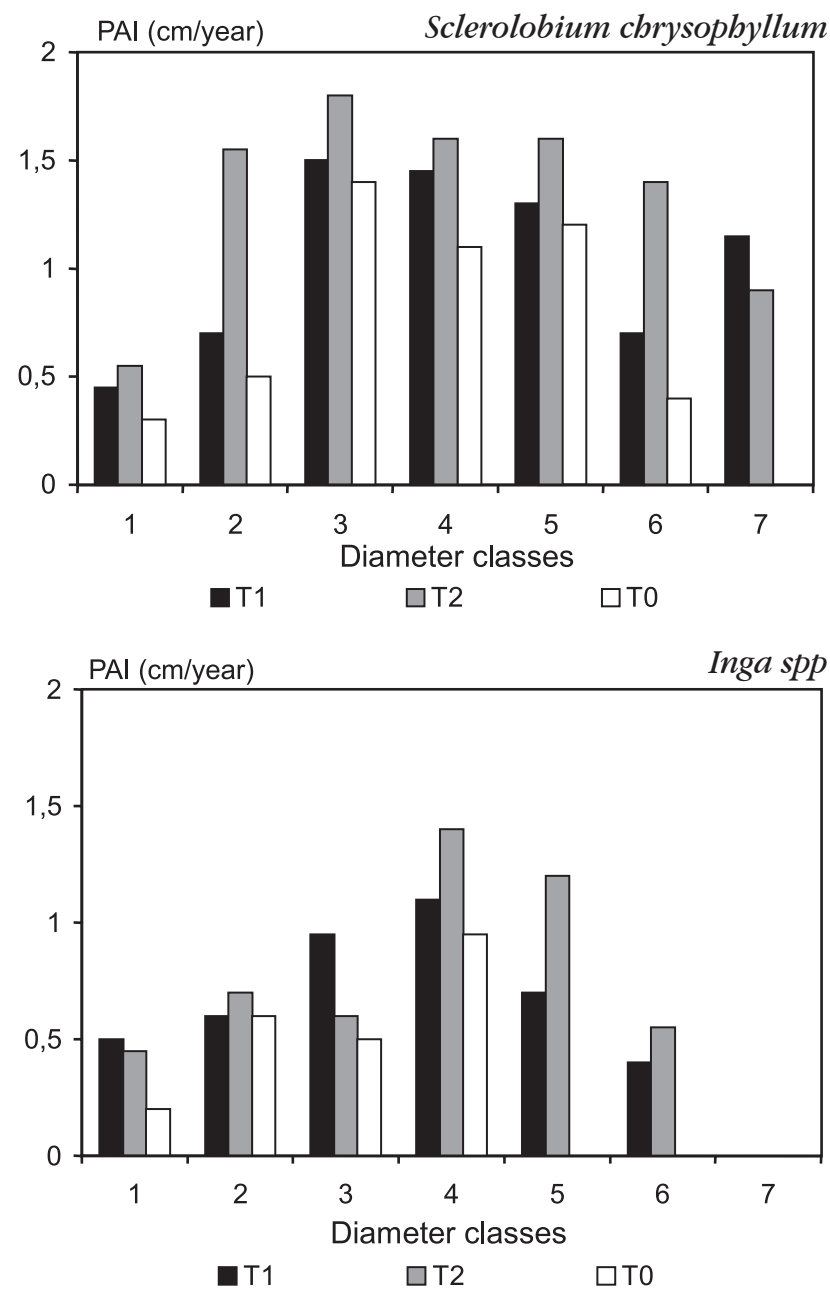

Figure 3 - Diameter increment by dbh classes of two lightdemanding species over an 8-year period in Brazilian Amazonia. $\mathrm{T} 1=\operatorname{logging} \geqslant 45 \mathrm{~cm}$ dbh $(14$ trees $/$ ha $) ; \mathrm{T} 2=\operatorname{logging} \geqslant 55 \mathrm{~cm} \mathrm{dbh}$ (11 trees/ha); To = unlogged area. 


\section{ACTA AMAZONICA}

GROWTH RATE OF A TERRA FIRME RAIN FOREST IN BRAZILIAN AMAZONIA OVER AN EIGHT-YEAR PERIOD IN RESPONSE TO LOGGING
Some shade-tolerant species such as Manilkara buberi and Parkia multijuga showed similar dbh increment curves in both forest conditions, but with low growth rate in the unlogged and very high in the logged. Other shade-tolerant species such as Geissospermum sericeum and Iryanthera juruensis showed similar dbh growth trend and similar increment rates in both logged and unlogged areas. Fig. 3 shows diameter increment by dbh class of two lightdemanding species, which represent the trend of many species of this ecological group. Sclerolobium chrysophyllum showed similar curves for the logged and unlogged forests, with higher increment in trees $15-55 \mathrm{~cm} \mathrm{dbh}$, with a peak on dbh class $3(25 \mathrm{~cm} \leqslant \mathrm{dbh}<35 \mathrm{~cm})$. Inga spp. showed higher increment on trees $35-45 \mathrm{~cm} \mathrm{dbh}$, and the peak was on $\mathrm{dbh}$ class $4(35 \mathrm{~cm} \leqslant \mathrm{dbh}<45 \mathrm{~cm})$. Significant differences between logged and unlogged forest were found only in the first $\mathrm{dbh}$ class for both species (Fig. 3). A notable number of lightdemanding species, represented by those in Fig. 3, had higher increment in the medium dbh size trees, while the rates in the larger diameter trees were still higher than those of the smaller individuals. This tendency was noted in both logged and unlogged forests.

The response of most of the shade-tolerant species were well represented by those of Pouteria bilocularis and Carapa guianensis, as shown in Fig. 4. Increment rates of both species were greater for trees $25-55 \mathrm{~cm}$ dbh in the unlogged forest, but some differences occurred in the logged area. Comparing the logged and unlogged areas, the response of Pouteria bilocularis showed significant differences in dbh classes 1, 2, 4 and 5, while that of Carapa guianensis differed in all classes except 5 (45-55cm), as seen in Fig. 4. Increment of Carapa guianensis was also significantly different between the treatments in the logged forest, in all dbh classes except 3 (25 $-35 \mathrm{~cm})$. The greater increment of Pouteria bilocularis occurred for trees of $15-25 \mathrm{~cm}$ dbh in the logged area; trees $>25 \mathrm{~cm} \mathrm{dbh}$ responded similarly to those in the unlogged forest. In contrast, Carapa guianensis showed a different increment curve for each treatment. Under heavier logging, its growth rate increased with increasing tree diameter, while in the lighter logging, growth increased up to class $3(25 \mathrm{~cm} \leqslant \mathrm{dbh}<35 \mathrm{~cm})$, then decreased with increasing diameter size. Its pattern of increment in the unlogged forest represented the most common tendency for shade-tolerant species in the undisturbed forest. In the logged forest, many shade-tolerant species had higher increments in the medium and large size classes (e.g. Carapa guianensis), but others showed high growth rates in the smaller classes (e.g. Pouteria bilocularis).

The 40 ecologically most important species, according to their Importance Value Indices (Carvalho, 2000) showed mean diameter increment rates $\left(\mathrm{T} 1=0.42 \mathrm{~cm}\right.$ year $^{-1}, \mathrm{~T} 2=$ $0.39 \mathrm{~cm} \mathrm{year}^{-1}$ ) above the average found for all species together in the logged forest. But their mean increment in the undisturbed area $\left(0.18 \mathrm{~cm}\right.$ year $\left.{ }^{-1}\right)$ was lower than for the
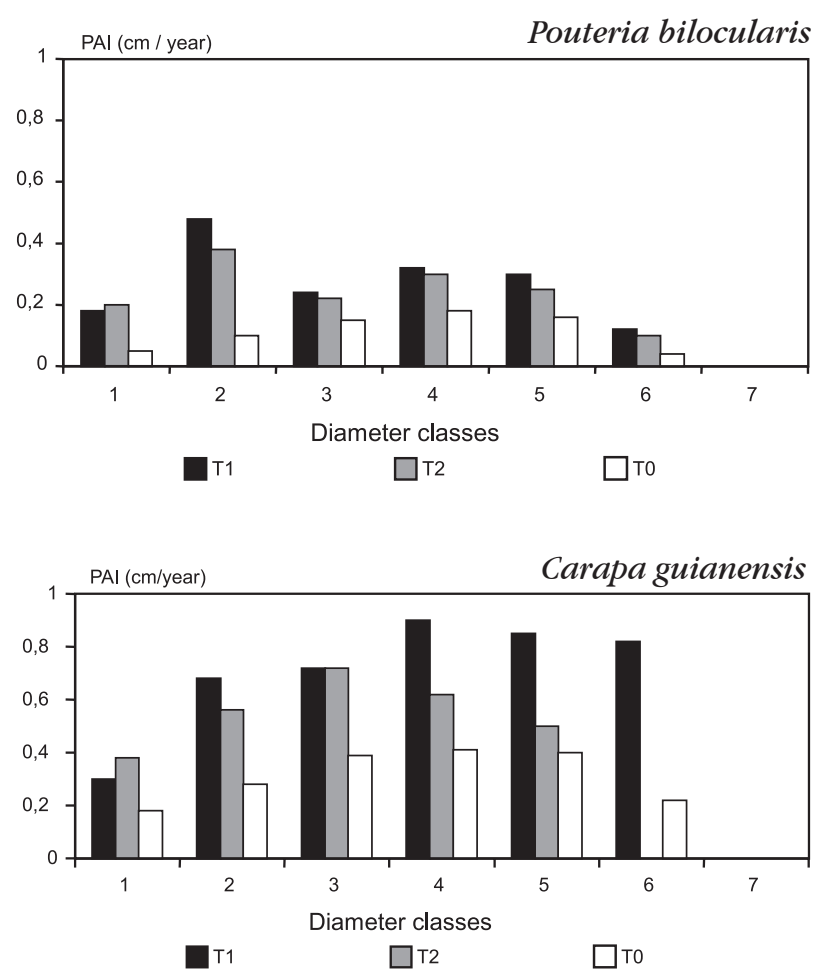

Figure 4-Diameter increment by dbh classes of two shade-tolerant species over an 8-year period in Brazilian Amazonia. T1 = logging $\geqslant 45 \mathrm{~cm} \mathrm{dbh}(14$ trees $/ \mathrm{ha}) ; \mathrm{T} 2=\operatorname{logging} \geqslant 55 \mathrm{~cm}$ dbh $(11$ trees/ ha); To = unlogged area.

Table 1 - Periodic annual diameter increment - PAI $\left(\mathrm{cm} \mathrm{ear}^{-1}\right)$ of the 40 ecologically most important species by ecological and wood quality group. $\mathrm{CV}=$ coefficient of variation (\%), $\mathrm{N}=$ mean number of trees per species.

\begin{tabular}{lccccccccc}
\hline \hline Species Group & \multicolumn{3}{c}{ Logging $>$ 45cm } & \multicolumn{3}{c}{ Logging $>55 \mathrm{~cm}$} & \multicolumn{3}{c}{ Unlogged forest } \\
\hline Light-demanding & PAI & CV & N & PAI & CV & N & PAI & CV & N \\
Shade-tolerant & 0.90 & 84 & 65 & 0.82 & 85 & 57 & 0.36 & 69 & 40 \\
Commercial & 0.28 & 37 & 41 & 0.26 & 43 & 44 & 0.13 & 47 & 55 \\
Potential & 0.47 & 37 & 31 & 0.43 & 37 & 36 & 0.28 & 82 & 22 \\
Non-commercial & 0.39 & 62 & 28 & 0.41 & 75 & 30 & 0.20 & 84 & 42 \\
All species & 0.42 & 136 & 61 & 0.36 & 138 & 59 & 0.15 & 77 & 67 \\
\hline \hline
\end{tabular}




\section{ACTA \\ AMAZONICA}

GROWTH RATE OF A TERRA FIRME RAIN FOREST IN BRAZILIAN

AMAZONIA OVER AN EIGHT-YEAR PERIOD IN RESPONSE TO LOGGING total number of species. Considering the ecological groups, the light-demanding species had growth rates about three times higher than the shade-tolerant species; and taking into account the wood quality groups, the commercial species grew faster than the potential and the non-commercial groups. Table 1 summarises the figures for diameter increment of the 40 ecologically most important species in the study area by ecological and wood quality groups.

\section{CONCLUSION}

Considering all species together, diameter increment was similar for both intensities of logging until five years after logging. Those after logging $\geqslant 45 \mathrm{~cm}$ dbh then showed a significantly higher increment until the end of the study period. Light-demanding species showed significantly higher growth rates than shade-tolerant species in the logged forest, with greater increment in the heavier treatment intensity. Commercial species also had higher growth rates in the heavier logged area, although those were significantly different only in the period from one to five years after logging.

In the undisturbed forest, growth rates increased with increasing dbh size. Large trees showed the greatest diameter increment during the entire study period. The increment of medium trees was intermediate, and the lowest increment rates were found in small trees from understorey species. In the logged forest, no significant differences in increment were found between size classes, except for small trees one year after logging $\geqslant 55 \mathrm{~cm} \mathrm{dbh}$, and for medium trees five years after logging. This probably occurred because all tree size classes experienced similar light conditions.

At species level, growth rate varied between and within treatments, as well as between trees within species, depending mainly on degree of canopy opening, among other environmental influences, and probably on genetic factors. Silvicultural management planning should take into account those particular species characteristics.

The logging favoured the growth of commercial species, chiefly the light-demanders. Therefore, if the same growth conditions continue being given, for example by silvicultural treatments, to those species of interest, the forest would reach a stock available for harvesting around year 30 after logging, taking into account the average diameter increments, considering that commercial species were above the average. However, the high variation in increment rates indicates that an eight-year period is not sufficient to allow predictions on cutting cycles or policyclic management systems for the study forest.

\section{LITERATURE CITED}

Alder, D. 1983. Growth and yield of the mixed forests of the humid tropics. FAO Report. Oxford (unpublished).

Begon, M. 1984. Density and individual fitness: asymmetric competition. In: Shorrocks, B. (Ed.). Evolutionary Ecology. Blackwell Scientific Publications, Oxford. p.175-194.
Carvalho, J.O.P. de. 1982. Análise estrutural da regeneração natural em floresta tropical densa na região do Tapajós no Estado do Pará. 1982. Dissertação (Mestrado em Ciências Florestais) - Universidade Federal do Paraná. Curitiba, 128p.

Carvalho, J.O.P. de. 2000. Classificação em grupos ecológicos das espécies mais importantes em uma área da Floresta Nacional do Tapajós, Belterra, PA. Belém: Embrapa Amazônia Oriental, 4p. (Embrapa Amazônia Oriental. Comunicado Técnico, 41)

Carvalho, J.O.P. de. 1992. Structure and dynamics of a logged over Brazilian Amazonian rain forest. D.Phil. Thesis. University of Oxford. Oxford, 215p.

Connell, J.H.; Tracey, J.G.; Webb, L.J. 1984. Compensatory recruitment, growth and mortality as factors maintaining rain forest tree diversity. Ecological Monographs, n.54. p.141-164.

Costa, D.H.M.; Silva, J.N.M.; Carvalho, J.O.P. 2004. Crescimento de árvores em 64 ha de terra-firme na Floresta Nacional do Tapajós durante 18 anos após a colheita de madeira. Submetido à Revista de Ciências Agrárias.

Dubois, J.C.L. 1976. Preliminary management forest guidelines for the National Forest of Tapajós. Belém: IBDF/PRODEPEF. 42p.

Fundação De Pesquisas Florestais Do Paraná - FUPEF. 1986. Relações entre solos e a vegetação natural em área da Floresta Nacional do Tapajós. Curitiba, FUPEF.

Gomide, G.L.A. 1999. Estrutura e dinâmica de crescimento de florestas tropicais primária e secundária no Estado do Amapá. In: SIMPÓSIO SILVICULTURA NA AMAZÔNIA ORIENTAL: contribuições do Projeto Embrapa/DFID, Belém, PA. Resumos expandidos. Belém: Embrapa-CPATU/DFID, 1999. p.195-202. (Embrapa-CPATU. Documentos, 123).

Hutchinson, I.D. 1982. Field enumeration of permanent sample plots in the mixed Dipterocarp forest of Sarawak. [S.1.]: FAO. (FAO. Report FO:MAL/76/008. Field Documents, 16).

Instituto Brasileiro de desenvolvimento florestal (Brasília, DF). 1988. Amazonian timbers: characteristics and utilization; Curuá-Una Experimental Forest Station. Brasília, 236p.

Instituto Brasileiro de desenvolvimento florestal (Brasília, DF). 1981. Amazonian timbers: characteristics and utilization; Tapajós National Forest. Brasília. 113p.

Instituto Brasileiro de desenvolvimento florestal (Brasília, DF). 1980. Woods from Tucuruí: characteristics and application. Brasília. 49p.

Kio, P.R.O. Stand development in naturally regenerated forest in South-Western Nigeria. D.Phil. Thesis. Iniversity of Ibadan. 1978.

Lieberman, D.; Lieberman, M. 1987. Forest tree growth and dynamics at La Selva, Costa Rica (1969-1982). Journal of Tropical Ecology, v.3, p.347-358.

Lieberman, D.; Lieberman, N.; Peralta, R. 1985. Growth rates and age-size relationship of tropical wet forest trees in Costa Rica. Journal of Tropical Ecology, n.1. p.97-109.

Manokaran, N.; Kochummen, K.M. 1987. Recruitment, growth and mortality of tree species in a lowland dipterocarp forest in Peninsular Malaysia. Journal of Tropical Ecology, v.3, p.315-330. 


\section{ACTA AMAZONICA}

Mervart, J. 1972. Growth and mortality rates in the natural high forest of Western Nigeria. Nigerian Forestry Information Bulletin (new series), n.22.

Mervart, J. 1974. Appendix to the paper on growth and mortality rates in the natural high forest of Western Nigeria. Nigerian Forestry Information Bulletin (new series), n. 28.

Miller, T.B. 1981. Growth and yield of logged-over mixed dipterocarp forest in East Kalimatan. The Malaysian Forester, n.44. p.419-424.

Nicholson, D. I. 1979. The effects of logging and treatment on the mixed dipterocarp forests of South-East Asia. FAO, Rome. Consutancy Report FO: MISC/79/8.

Rai, S.N. 1981. Rate of growth of some evergreen species. Indian Forester, n.107, p.513-518.

Silva, J. N. M; Carvalho, J. O. P. De; Lopes, J. do C. A. 1985. Inventário florestal de uma área experimental na Floresta Nacional do Tapajós. Boletim de Pesquisa Florestal, n.10/11: p.38-110.

Silva, J.N.M. 1989. The behaviour of the tropical rain forest of the Brazilian Amazon after logging. D.Phil. Thesis. University of Oxford. Oxford. 302p.

Silva, J.N.M.; Carvalho, J.O.P.; Lopes, J. do C.A.; Almeida, B.F. de; Costa, D.H.M.; Oliveira, L.C. de; Vanclay, J.K.; Skovsgaard, J.P. 1995. Growth and yield of a tropical rain forest in the Brazilian Amazon 13 years after logging. Forest Ecology and Management. n.71, p.267-274.

Silva, J.N.M.; Carvalho, J.O.P.; Lopes, J. do C.A.; Oliveira, R.P.; Oliveira, L.C. 1996. Growth and yield studies in the Tapajós region, central Brazilian Amazon. Commonwealth Forestry Review, v.75, n.4, p.325-329.

Silva, J.N.M.; Lopes, J. do C.A. 1984. Inventário florestal contínuo em florestas tropicais: a metodologia utilizada pela EMBRAPACPATU na Amazônia brasileira. Belém: EMBRAPA-CPATU. (EMBRAPA-CPATU. Documentos, 33).

Sing, S.P. 1981. Growth and yield of mixed tropical natural forests of India. Reported prepared for FAO, Rome. (unpublished).

SUDAM. 1981. Grupamento de espécies tropicais da Amazônia por similaridade de características básicas e por utilização. Belém, SUDAM.
Swaine, M.D. 1990. Population dynamics of tree species in tropical forests. In: Holm-Nielsen, L.B.; Nielsen, I.C. \& Balslev, H. (Eds.). Tropical forests - Botanical dynamics, spaciation and diversity. Academic Press, London. P.101-110.

Swaine, M.D.; Hall, J.B.; Alexander, I.J. 1987. Tree population dynamics at Kade, Ghana (1968-1982). Journal of Tropical Ecology, v.3, p.331-345.

Swaine, M.D.; Whitmore, T.C. 1988. On the definition of ecological species groups in tropical rain forests. Vegetatio, v.75, p.81-86.

Synnott, T.J. 1979. A manual of permanent plots procedures for tropical rain forests. Tropical Forestry Papers, v.14.

Tang, H. T.; Wan-Razali, M. 1981. Report on growth and yield studies in inland mixed indigenous forests in Peninsular Malaysia. Paper prepared to FAO/IUFRO meeting on growth and yield studies in mixed indigenous forests, held in Los Banos, Phillipinas, January 1981.

Texeira, D.E.; Santana, M.A.E.; Souza, M.R. de. 1988. Amazonian timbers for the international market. Brasília: IBDF/ITTO. (ITTO. Technical Series, 1).

Weaver, P.L. 1986. Hurricane damage and recovery in the montane forests of the Luquillo Mountains of Puerto Rico. Caribbean Journal of Science, n.22. p.53-70.

Whitmore, T.C. 1990. An introduction to tropical rain forests. Oxford: Clarendon. 226p.

Whitmore, T.C. 1989a. Canopy gaps and the two major groups of forest trees. Ecology, v.70, p.536-538.

Whitmore, T.C. 1989b. Changes over twenty-one years in the Kolombangara rain forests. Journal of Ecology, v.77, p.469-483.

\section{RECEBIDO EM 08/04/2002 \\ ACEITO EM 04/05/2004}


